\title{
INFLECTION AND DERIVATION IN VERBAL MORPHOLOGY: A BORDERLINE CASE FROM AGGLUTINATIVE LANGUAGES
}

\begin{abstract}
A bstract. Nkollo Mikołaj, Inflection and derivation in verbal morphology: a borderline case from agglutinative languages. Studia Romanica Posnaniensia, Adam Mickiewicz University Press, Poznań, vol. XXXI: 2004, pp. 393-406. ISBN 83-232-1353-4, ISSN 0137-2475.
\end{abstract}

The present paper focuses on the linguistic status of causative formatives in Kazakh verbal morphology. In Kazakh traditional grammars, these morphological elements are claimed to represent factitive voice. Hence, they are viewed as an instance of inflection. This point of view is subject to thorough investigation. It is argued that word's single occurrence cannot cumulate several values of one grammatical category (e.g. nouns are never doubly marked for the category of number, adjectives are never carriers of more than one value within the category of degree, etc.). Kazakh verbs, in their turn, are able to contain the factitive and passive (or reflexive) morpheme at a time. The reason of this compatibility lies in merely derivational (non-categorial) nature of causative modifiers in verbal morphology of Kazakh language.

The distinction between inflectional and derivational morphology has stimulated the interest of scholars since the foundation of modern linguistics in the early $20^{\text {th }}$ century. This tendency is still present in linguistic textbooks as well as in theoretical discussions held only in a restricted circle of morphologists. So strong a commitment to this matter seems to be a proof of its vital importance. The separation between the two fields of research in question is crucial when a decision concerning the number of lexical entries to be put in a dictionary has to be made. The linguists agree that inflectional changes produce the paradigm of a single lexeme. Hence, they are not conducive to several distinct lexical items. This explains why the forms animal and animals, or $I$ and $m e$ ate not allotted separate entries. Since each of the above forms represents an inflectional extension of the basic word, their individual treatment would be unproductive.

It is also widely recognized that variable lexical items are carriers of categorial values discernible in a given part of speech. These values are expressed by means of 
inflectional morphemes. ${ }^{1}$ The latter are, therefore, obligatory components of every occurrence of the word susceptible to be varied. For example, Polish nouns are bound to convey information about the case, as well as number (Banko, 2002: 142148). In derivational morphology, the affixes, when combined with a root, always produce a new lexical item (sect and sectarian, to close and to disclose, canto and cantito, etc.). The result of such a combination can be, in its own way, inflectionally modified. The conclusion to be drawn from these examples is that a root and the word we derive from it cannot be considered to represent two paradigmatic variants descending from a single lexeme (Nagórko, 1993:206). Hence, a lexicographer should insert such pairs of words into two separate dictionary slots.

The present discussion aims at shedding a new light on the fuzzy boundary that separates two areas of linguistic research. The empirical material brought under analysis comes from Kazakh verbal morphology. Kazakh is an agglutinative language. Thus, in the conjugation, pieces of information about particular values of such categories as number, person, voice and tense are transmitted separately. As for aspect and mood, they are expressed partially via inflectional endings, partially via auxiliary verbs and relevant participial forms. Finally, it should be borne in mind that Kazakh verbs can contain a separate morpheme serving to express negation (Шырқыммызды бұз-ба «don't disturb us» as opposed to Шырырқымызы бy3 «disturb us»). The same holds true of nominal inflection where case, number and possession have overt exponents and, hence, are neatly segmentable (i.e. are not realized cumulatively). This state of affairs is, therefore, qualitatively different from what we know about flexive languages such as Latin, Greek or Slavic where words marked for more than one category form an inextricable combination. In nominal morphology of these languages, a single ending dispenses simultaneously all necessary details conceming number, case and gender, as can easily be seen in Latin word civ-ibus «to the citizens». It is hard to say what is responsible, within the -ibus morpheme, for expression of dative, and plural (see the notion of «cumulative exponents», Matthews, 1991:179-181). The mergers of the same kind extend to conjugation in these languages, although several exceptions from this general rule do exist (Heinz, 1961:352).

As said, the obligatory and recursive character comprises two main features of

'A certain confusion reigns in contemporary linguistics as to how the notion «inflection(al)" should be understood. This term designates primarily a branch of morphology oppositc (but complementary) to derivation (or word-formation), irrespective of the type of language dcalt with (analytic, isolating, alternating, etc.). «Inflection» is meant here to refer to a set of phenomena that express different values of grammatical categorics discernable in a given language. Furthermore, it is interpreted so as to account for the diversity of mcans uscd to convey information about these categories. We treat as inflectional both bound (such as personal endings) and free morphemes (for example, auxiliary verbs). As A. Spencer (2000:337) points out, inflection also embraces such exponents as word order, clitics, intonation, adpositions or combinations of these (see also Bańczerowski, 1999a:486-498 and for a slightly different point of view Wojcik, 2000:22-24). 
verbal inflectional endings in Kazakh. Every verb's occurrence appears either as singular or as plural. Additionally, it has to fit in with exclusively one grammatical person. Inflection also transmits information about where the process is situated with respect to the moment of utterance or with respect to some other process alluded to earlier. It needs to be emphasized that separate morphemes within the structure of verbal lexical items convey each one piece of this information. Kazakh verb may also act as the basis for a series of affixal modifiers. We are, then, in front of derivational processes. The latter are obviously less regular than agglutinative variations. $^{2}$ It is not infrequent that one and the same meaning is transmitted by numerous formatives. Let us look at standard Kazakh agent nouns. Such a semantic change is induced by the following suffixes: -ui (-ubl, as in қорzay-uы «barrister» taken from kyopzay «to defend»), -гep (with its combinatorial variants, see 6acnaгер «editor» derived from басу «to print») or -мен /-ман (оқыр-ман «reader» from oky «to read»). Unlike the inflectional modifiers, the derivational affixes are not obligatory within the structure of a sentence. The form aH («hunting») is able to fulfill the same syntactic functions (subject, adnominal complement, apostrophe, etc.) as аңзыb («hunter»), a noun to which, morphologically, it gives birth. Finally, derivational formatives are often viewed as triggering change of the part of speech a new lexical item belongs to (see $7 u-y$ «to fly» - $¥ u$-ak «airplane», mapm-y «to twist, to grind» - (em) mapm-қ̧ы «meat grinder»).

It seems clear that the number of categorial and derivational formatives does not render the distinction between the two fields of investigation any easier to go through with. One of the most curious instances of this confusion in Kazakh pertains to morphemic structure of factitive verbs. Every verb in this language is able to acquire causative meaning due to the agglutination of one appropriate

${ }^{2}$ One of the most salient characteristics that bears witness to a lesser, compared to the case of categorial formatives, regularity of affixes concerns the extent to which they comply with vowel harmony (often called synharmonism) and progressive assimilations. Both these factors play a crucial role in formal description of Kazakh inflectional and derivational morphemes. Every vocalic segment, whether appearing in the affix or inflectional ending, must inherit the feature \pm anteriority of the last vowel of the root. Examples: жылдам - жылдам-bipaқ ("fast» and "faster», back vowels aftcr $a$ ) and $\kappa o n-\kappa \theta б \cdot i p e \kappa$ («much» and «more», front vowels after $\theta$ ), күm-e-мin («I wait», front vowels after $y$ ) and шыг-a-мын («I leave», posterior vowels after ы), қала-лар-ыafter $a$ ) and кonip-лep-i-нde («on his bridges», front vowels after $i$ ). This formal constraint has an equal effect on derivational morphemes. However, since Kazakh abounds in numerous borrowed affixes (especially coming from Persian or Arab, sce Johanson, 1998:329), many of them do not comply with this principle. Examples: майim-xaнa («mortuary», coming from мaũim «cadaver, corpse»), иеберxана («master's workshop», derived from иебер «master»), дәрет-хана («toilettes»). Inflectional formatives do not rebel to such an extent against the principles of synharmonism. There are only two categorial morphemes that depart from this general rule. The endings of instrumental-comitative case contain exclusively front vowels (back series does not exist, see aйbımaynu-мен бірге "with a prosecutor»). The element $-a k$, used to complete the expression of superlative within a category of degree (sec axiniumi-ak «extremely sorry»), is another exceptional morpheme from this point of view. This time, front vowels are absent. 
morpheme selected from an entire series. Let us take an example. The stative verb $m_{Y p}-y$ «to stand» may undergo such a modification so as to, eventually, result in the form myp-zbl3-y «to put up, to cause something to stand». The formative -zbl3- has a wide range of combinatorial variants. These arise from phonological features of root's terminal segments, жyp-y «to go, to move»-жүp-zis-y «to bring to motion, to drive», жеm-y «to reach (a specified point)», жеm-кіз-y «to supply, to make reach (a specified point)» or aüm-y «to tell» - aüm-қ̧ыз-y «to make someone say something». Traditional Kazakh grammars rank this transformation among one of the values within the category of voice. This opinion is so deeply ingrained that -zblz- and its allomorphs are claimed to have an inflectional status. Hence, the verbs жүр-гіз-у, айm-қызз-y, жет-кіз-y, тұр-выз-y and their homologues are often considered to represent a factitive voice. It is this point of view that we shall submit to further investigation.

In order to pin down the boundary between inflection and derivation, we can avail ourselves of the order in which the appropriate morphemes are agglutinated to the root they modify. According to the claim made above, inflectional endings supply information about categorial status of lexical items to which they are attached. It should be borne in mind, however, that nothing prevents these items from being morphologically complex. Morphological complexity is the effect attributable to the presence of derivational affixes which cause lexical alterations in the meaning of initial forms. Hence, many scholars argue in favor of more central position of lexical formatives with respect to the root. Inflectional endings are attached afterwards. Consequently, they are more peripheral compared to derivational morphemes. It seems logical that in order to inflect the lexical item it has to be known. It is the derivationally modified stem that is determined as to particular values of categories it represents (i.e. specified, as in the case of verbs, for person, number, mood, tense, aspect, voice and so on) and not vice versa (see Corbett, 1987: 327-328).

As far as Kazakh language is concerned, the situation is best exemplified by successive extensions of the verbal root жem-: («reach», 2 PER. SING. IMP.), жет-кіз («make reach, provide, supply», 2 PER. SING. IMP.), жет-кіз-y («to supply, to make reach, an instance of supplying»), жеm-кiз-y-ui («provider, supplien»), жет-кіз-y-ui-лер-iм-e («to my suppliers, to my providers»). The basic item жcm-becomes, as we see, a foundation for further, lexical and inflectional, extensions. The question then arises to what linguistic results these agglutinations are conducive. First of all, they seem to entail non-trivial lexical modifications of the initial form. As is generally known, these modifications are traditionally brought about by derivational formatives. Secondly, successive agglutinations to xem-make precise the categorial values of the resulting lexical item. Finally, there is a transfer between parts of speech: a verbal root becomes an inflected noun. When these changes are thoroughly inspected, we see that they follow a certain order. The specification of the set of categorial features of жеm-кiз-y-ui takes 
place at the very end. The first inflectional element is a plural ending (-nep-). Then, a possessor is marked (-iM-). Finally, directive-dative casual morpheme $(-e-)$ is agglutinated. In Kazakh language, the categories of number, possession and case characterize exclusively nouns and pronouns. It is not surprising, then, that we expect the change of the part of speech to have been induced prior to the specification of nominal categories. This change is to be assigned to two derivational formatives $-y$ - and $-u i$ -

The latter transforms verbal roots it modifies into agent nouns (жem-ki3-y-ui means «provider, one who provides»). The $-y$ - suffix ranges initial form among either infinitives or deverbal action nouns («the action / the instance of providing»). So, both elements assume a double function: they introduce lexical change in the

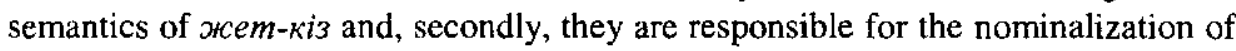
the verbal stem. At the same time, they both precede the morphemes of case, possession and number. This ordering reveals linguistic status of the morphemic adjuncts to Kazakh words. Since causative formative $-\kappa i 3-$ is the first one that modifies жem-, it is clear that it is devoid of any functions related to the expression of grammatical categories. These obviously belong exclusively to the realm of inflection. The above demonstration presents, therefore, the first argument against categorial character of factitive modification in the Kazakh language.

Yet, the provided solution does not go unchallenged. It is possible to adhere to an alternative point of view and to claim that causative formatives (-zblz- and its variants) are an inherent part of derivational base. It is only the latter that is subject to subsequent lexical and, depending on a part of speech imposed by last derivational morpheme (cf. Williams, 1981:269-272), inflectional extensions. Such solution remains neutral as to categorial or merely derivational status of factitive endings. ${ }^{3}$ Besides, voice is strictly a verbal category, whereas жет-кіз-y-ui-лерin-e is clearly a noun. Accordingly, the argument to adopt the ordering of derivational and inflectional morphemes as a criterion for distinction between two fields of research proves to be of little assistance to us here.

Another stage in our efforts toward ironing out the puzzle concerning linguistic status of factitive modification is to resort to the definition of voice. It is under this label that Kazakh traditional grammars classify causative verbs. Voice is a grammatical category closely knit to verbs and, when necessary, to their auxiliaries.

${ }^{3}$ One might object that factitive morphemes are not endings, but infixes. In fact, causative structural elements are often, visually, inserted in the very middle of a word (as in жет-кіз-бе-й-міз "we do not supply», omыр-zыз-blybł-dap - "plant», 2PER. PL. IMP., om-кіз-iл-zeн - «have been undergone", etc.). It should, however, be noticed that, although -zbls- (and its allomorphs - kiz-, -zis- and . қыз-) always precedes other elements (both derivational and inflectional) within linear structure of a given lexical item, it is always posterior to the verbal root it is attached to. The latter is identifiable as imperative $2^{\text {nd }}$ person singular. So, the terminal position of causative morpheme in the form $\% e m-\kappa i 3$ "supply» is not surprising at all. This leads us to recognize that Kazakh is a language where infixation does not apply. 
Its role is to single out the set of possible hierarchies of nominal items that accompany verbs within a sentence. These nominal elements are expressed either obligatorily or according to the language user's preference. It should be borne in mind that one of the peculiar features of voice is its inflectional character, which means that this category is expressed either by means of specialized bound morphemes or by means of a restricted range of auxiliary words. Other kinds of constructions related to the alignment of grammatical relations (such as lexical converses, abstract nouns with light verbs, etc.) are not articulated inflectionally. In addition, the form adopted by a verbal lexical item identifies syntactic functions assumed by nominal elements within linear structure of the sentence. Several authors (see Bybee, 1985:83) impose another constraint on morphological changes related to the expression of voice. According to them, as long as we are within the domain of inflection, the number of syntactic slots (or, roughly speaking, of arguments) required by a verbal form cannot change after morphological transformations are carried out. This is conspicuous in Latin sentences Gutta cavat lapidem («Dripping water drills a stone») and Lapis cavatur gutta («A stone is drilled by dripping water»). The author, as well as the object of the action, are expressly mentioned here. This definition has also the advantage of taking into account constructions other than passive and active. The number of arguments is also preserved after reciprocal transformation (John sells cars to Tom and John and Tom sell cars one to another, see Dalrymple and others, 1999: 175-177). More problems arise with respect to reflexive constructions (Sheila is washing hands and Sheila is washing herself, should the noun and the pronoun be treated as coreferential arguments?). Nominal items are, if anything, displaced in these constructions, but their number does not vary.

An intriguing question is why this criterion is allotted so much importance when the difference between inflection and derivation is discussed. Those who argue in favor of the principle to preserve a number of arguments point out that the addition (or subtraction) of one of the participants in relation, profoundly alters the nature of extra-linguistic situation signified by the predicate and its arguments. A good example is the verb to die, a single place predicate whose meaning suggests that two successive states of affairs are involved. The individual (identified by the verb's only argument) who is alive dies (see Åquist, 2002: 325-328 about ontological components of the notion of cause). Not quite unexpectedly, the meaning carried by to die is incorporated in this of to kill. The latter restates all what stems from the semantic contents of the former. It adds, however, another piece of information, namely that there is a causer. Single-place predicate acquires, in the way, a new argument. Consequently, its meaning changes considerably. Since no categorial change intervenes here, such cases are clearly to be viewed as an instance of derivation. As was asserted above, Kazakh language marks the difference between such pairs as to die and to kill by means of a suffixal modification. The verb өлу («to die») takes on the form ол-mip-y «to kill» (the morpheme -zыз- and 
its combinatorial equivalents referred to above are not the only ones which facilitate the expression of cause). The argument structure of the modified verb changes accordingly. It should be highlighted that the gap between олу and өлтіру is, first and foremost, semantic in its nature. The syntactic level, i.e. the number of arguments, only mirrors changes in meaning between two lexical items. Both to die and to kill, as two derivationally related lexical items, have to be inserted into two distinct dictionary entries.

When a closer look is taken at structural modifications a sentence undergoes after the category of voice changes its value, a series of exceptions to the principle of preservation of the number of arguments can be discerned. For instance, a series of Polish expressions halasowano, widziano, potaczono as derived, respectively, from halasować («to behave noisily» monadic), widzieć («to see», two-place predicate) and polqczyć («to join», combinable with three arguments). The use of these morphological variants necessitates the erasure of one of the arguments that accompany finite verbs. The element that is subject in active voice must disappear. Its preservation is prohibited for grammatical reasons (*staruszkowie hatasowano za ścianq, «elderly people, one has made noise behind the wall» is ill-formed). It should be noted that the discursive role of these forms is to avoid an explicit mention of one of the participants in extra-linguistic situation signified by the verb and by its arguments (see Karolak, 1990:131-134, Paduceva, 2002:183). This pragmatic status of the verbs under discussion explains why they are defective with respect to the category of grammatical person. Nevertheless, the regularity of these forms (they are derivable from almost every Polish verb) and their ability to underlie syntactically complete sentences (as in Za ścianq hatasowano przez cala noc «It has been, all night long, noised behind the wall», which has clearly categorematic status) strongly suggests to treat them as paradigmatic (nonderivational, hence inflectional) variants in Polish verbal morphology. It would be a shear vagary to classify hatasowano, widziano, polaczono and their corresponding personal forms individually and to insert them twice in a dictionary.

An analogous situation occurs in French verbal morphology. Let us put to the test the relation between vendre and its pronominal counterpart. If the latter does not mean that the action is either reflexive (as in Elle se vend au premier venu «She sells herself to anyone who asks») or reciprocal (as in Ils se vendent les voitures l'un a l'autre "They sell cars one to anothen»), the noun denoting the vendor may not, again for syntactic reasons, be uttered. If this argument is hidden, the resulting construction is semantically equivalent to the one in passive voice. The sentences Le blé se vend bon marché, *Le blé se vend bon marché par les fermiers and Le blé est vendu bon marché par les fermiers corroborate that (Lamiroy, 1993:247-248). The foregoing illustration proves that the disappearance of one argument is obligatory. However, since these modifications deal with categorial characteristics of vendre (active $v s$. passive voice), it would be hard to deny their inflectional (and consequently non-derivational) character. Both forms will be treated only once in 
a lexicon. Verbal morphology of Romance languages is permeated with this kind of structural processes. The question arises whether the Kazakh causative modification can be viewed as an instance of voice, categorial and inflectional in its nature, or merely as a derivational phenomenon. The fact that there is a change in combinatorial properties of the factitive verb compared to those of the lexical item from which it originates does not determine the linguistic status of the former. ${ }^{4}$

In order to solve this problem, some basic facts about the presence of grammatical categories within words' occurrences need to be invoked. These are not able to contain more than one value of a given category at a time. That is why the Spanish noun for children will be either plural (hijos) or singular (hijo), but not both singular and plural at the same time. Similarly, a unique instance of the personal pronoun in English is never - simultaneously - nominative and oblique within a single category of case (either $I$ or $m e$, but not both at the same time). This principle holds true equally well for all natural languages that possess inflection. The occurrences of Kazakh and Latin adjectives қысқарақ («shorter») and clarior ("clearer» or «more famous") both expressing comparative value within the category of degree, cannot take, for obvious reasons, superlative morphemes (*қыn-қысқарақ and *clariorissimus, respectively). Likewise, actual realizations of verbal lexical items are subjects to this constraint with respect to the category of voice. Active verbs exclude passive ones and vice versa (see ${ }^{*} \mathrm{He}$ is steals precious stones and *Precious stones are stolen steals by him). Reciprocal constructions will not be, simultaneously, reflexive and passive, etc. To put it simply, in the expression of one and the same grammatical category, the exponents of its respective values are never cumulated in word's single occurrence.

In spite of this obvious postulate, several researchers claim the contrary and prove they find two distinct values of a single category in the same occurrence of an inflected word. ${ }^{5}$ They evoke, in the course of their reasoning, such forms as Kazakh

${ }^{4}$ Goldberg (2001:506, 510-514) highlights many instances of systematical ellipsis of one of nominal constituents that accompany causative verbs (which are two or more place predicates). These structural variants are most frequent in habitual and potential sentences (Tigers always kill at night, These revolutionary new brooms sweep cleaner than ever). Another kind of construction where one of the arguments is eliminated is that where predicative expression imposes evident semantic restrictions on its arguments (It is good to recycle as opposed to *John is breaking, where the meaning of to break is not sufficiently clear to give up one of the participants in the extra-linguistic situation it signifies). Finally, an argument may be omitted when it contributes poorly to the information structure of the sentence. Such a nominal clement does not lend itself to be focused (cf. *The singer always aimed to dazzle people, *Tigers only kill at night. They are easily caught at that time, stressed nominal constituents are not jtalicized). The omission is obligatory in such cases. Numerous prosodic phenomena (e.g. placement of accents, division into phonological segments) seem to confirm that. All this does not alter, however, the categorial status of verbal form, which still belongs to the paradigm and there is no need to allot a distinct lexical entry to it.

${ }^{3}$ Two apparent counter-examples to this principle were brought to light so far. The first of them pertains to French prepositional phrases with partitive quantification (écrire avec de l'encre, acheter 
noun $\partial o c-b L m b l 3-z a$ («to our friend»). Дoc, pure and simple nominative, is followed here by POSS. 1 PLUR. morpheme which, in its turn, precedes the ending of dative case. The question, then, arises whether it is justified to claim coexistence, within doc-blмbl3-za, of two cases - nominative and dative. There are several reasons why such an assertion needs to be dismissed. The expression of values of different categories may occasionally involve solely a set of specialized endings. However, certain forms, particularly those that are interpreted as unmarked (such as singular number, active voice or nominative case), do not have any distinct markers within their structure (or, to put it another way, they have zero exponents). Other inflectional forms are built upon them, usually by means of a series of adjuncts added to the unmarked form. It seems, then, that two distinct categorial values within word's single occurrence can be recognized. Such is the status of the paradigm of the Polish noun park (NOM. SG.). The remaining casual values are either built on it or homophonous with it: park- $u$ (GEN. SG.), park-owi (DAT. SG.), park (ACC. SG.), park-u (LOC. SG), etc. It does not follow, however, that such forms as parku or parkom (DAT. PL) are doubly marked for case. Formal syncretisms that appear sometimes between two (or more) forms are not relevant with respect to this principle (see Boguslawski, 1992:71-73).

Another argument to be adduced in favor of the mutually exclusive character of two values of a single category inside one word's occurrence is provided by the observation of syntagmatic properties of inflectional markers (whether agglutinative or flexive ones). Affixes, adpositions, inflectional endings as well as derivational morphemes are synsemantic. Their peculiarity relies on the fact that they are unable to occur autonomously. Taken in isolation, they are devoid of any semantic contents. The only reason for their existence is to modify categorial status of free

avec de l'or, etc.). According to Kempf ([975:150-151), such constructions are doubly marked for the category of case. It seems that in their structure instrumental as well as partitive cases can be recognized. However, all this reasoning is clearly based on the misinterpretation of what partitive NPs actually are in French. It is true that there is a special inflectional form for partitive in such languages as Finnish which is used when dealing with what is often referred to as "inalienable possession" - the objects which are inherently possessed by a certain totality (for instance, body parts with respect to the whole body) have to be marked with appropriate endings (see Bally, 1926/1996:48-52). However, partitive in French should be viewed as belonging to the domain of nominal quantification and not to the case understood here as a means of marking dependent nominal elements for the type of relationship with their head. The partitive information in French does not assume this function (cf. De Carvalho, 1996:182-184). Other controversy is generated by the existence, in nominal morphology of Turkic languages, of such formations as may-nap-ы-лдa-zы-лың (i.e. mountain-PL-3 POSS-LOCPRON.-GEN, "of one who is in these mountains», Kazakh) or tarla-lar-tn-ki-ler-in (i.e. field-PL.GEN.-PRON.-PL.-GEN., " of those belonging to the fields", Turkish, the example quoted after Plank, 1999:284). In the first of the above examples, there are, effectively, locative as well as genitive cases. However, the second of them pertains to the preceding pronoun and not to may. The same applies to the Turkish example. All in all, it is not legitimate to maintain that two values of a single category are cumulated in such nominal items. 
forms. The same applies to intonation (Nkollo, 2002:133-134) and word order. Consequently, the linguistic status of досыьмызza is equivalent to that of Polish forms deriving from park (see Bańczerowski, 1999b:47).

In Kazakh conjugation, reflexive, passive and reciprocal voice are morphologically built on active voice. In other words, there is a series of specialized formatives that, agglutinated to a verbal root, carry the meaning of passiveness, reciprocity or reflexivity. They are the following morphemes: $-i л-(-b \iota /-/ \Omega-$, according to the tenets of synharmonism and of progressive assimilation) as in тексеру «to supervise» and тексерілу «to be supervised, to be controlled» (passive), -iH- (-blH-/-H-), as in meкcepiny «to control, to supervise oneself» (reflexive voice). Finally, for the reciprocal voice we have -ic- morpheme (-bic-/care its combinatorial variants, see тексер-ic-y «to supervise, to control each other»). Such morphological modifications are fully regular, disregarding alternations for which phonology is responsible. As for causative verbs, they are also underlain by active forms (тексер-ткіз-y, «to order to supervise someone»). However, the element -zi3- and its allomorphs are not the only ones that introduce causative meaning (in Жаңа мақалада сенің сөздерің келтірілген "your words were quoted in a new article», Тышқан кедениілерден өлтірілмеген «the mouse was not killed by customs officials", the verbs келтірілген and өлтіріимеген contain the formative -mip-; their initial elements $\kappa e s$ - and $\theta l$ - mean «to come» and "to die», respectively). The accumulation of several values of the category of voice is prohibited in Kazakh verbal morphology. That is why active and passive cannot co-occur inside one and the same lexical item. The same holds true of combinations: passive and reflexive, reflexive and reciprocal, reflexive and active and so on. This orderly panorama changes radically when dealing with factitive verbs. They are not only morphologically derived from corresponding active forms, but also easily combinable with other values discernible within the category of voice. This is what happens to the above-mentioned two verbs (келmipinzen and onmipisuezen). The factitive morpheme neighbors in both cases with the element -iz- which is, beyond any doubt, the exponent of passive voice.

We might wonder why these two formatives are allowed to appear one with the other within a single word's structure. The only logical answer to this question is that passive and causative meanings are not mutually exclusive. The reason of this compatibility lies in merely derivational (non-categorial) status of -zbl3-, -mip- and their variants. In fact, these elements can be followed, in a linguistically natural and non-exceptional way, not only by passive, but also by reflexive morphemes (what leads to kesmipiny, «to evoke oneself, to quote oneself» or onmipiny «to kill oneself, to commit suicide»). As we see, causative verbs are already inflected with respect to the category of voice. If particular values of the latter cannot be cumulated, an instance of combining more than one of them inside a single word would contravene to one of the most fundamental and universal features of inflection. Therefore, what we are dealing here with, is derivational modification. 
Causative morphemes in Kazakh language do not represent grammatical category of voice.

Apart from what has been put forward so far, there is a number of arguments that support the hypothesis about derivational, rather than inflectional, nature of factitive change in Kazakh language. However, contrary to what is the case with the principle of non-accumulation of several categorial values, these arguments are conceptualized in terms of «more or less». Unsurprisingly then, the facts that we shall allude to here are rather a matter of degree instead of «either-or» choice. The first such argument relies on the number of morphemes responsible for conveying factitive meaning. Apart from -zbl3-, the derivational formative - mip- (jointly with

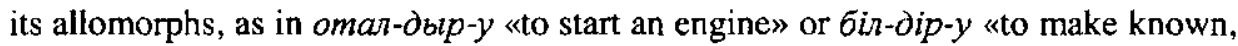
to communicate») has been already mentioned. These two forms are not the only ones; there is a bundle of other morphological elements capable of transmitting the same piece of information. On the other hand, inflectional formatives distinguished inside the category of voice (in this case passive, reflexive and reciprocal) are differentiated only with respect to the principles of symharmonism. They are far less diversified than causative elements. The reason why the exponents of the latter are so numerous stems from their derivational nature. In a word, affixes are greater in number and more differentiated in their form than the exponents of grammatical categories (Beard, 1998:45). It is particularly conspicuous when examining agent nouns in Polish and the number of suffixes responsible for introducing this semantic value: wyklad-owca («lecturen)) and zwiad-owca («recon-naissance soldier»), handl-arz («merchant») and koszyk-arz («basketball player» or «basket maker»), fabryk-ant («manufacturer, factory's owner») and spekul-ant («speculator, stock exchange customer»), kup-iec («trader, merchant») and zawodow-iec («professional»), etc. The number of Kazakh causative formatives follows the same mechanism.

Factitive elements are also less regular when it comes to their semantic properties. Unlike inflectional categories in verbal morphology, where the correspondence between meaning and form is one-to-one (one sense has only one material exponent), causative meaning is often expressed, so to speak, at random. Although the semantic effect of the agglutination of factitive morphemes is always the same (one may easily foresee what the difference between mұpy and mұp-zbl3-y is), there are verbs whose meaning is causative even when appropriate formatives are absent in their structure. One of the most blatant examples of this irregularity is the couple of verbs жабy and auy («to close» and «to open», respectively; the first can be paraphrased as «cause become not open» and its partner as «cause become open»). Although, the meaning of each clearly hints at some cause, the morphology does not mirror this semantic feature. When appropriate formatives are agglutinated to open something. Syntagmatic status of categorial formatives is, in this respect, comple-tely different - once they are present, a semantic change is completed in the 
structure of the word. Otherwise, the verb does not convey passive, reciprocal or reflexive meaning.

An additional feature may be relevant to our investigation when attempting to precise combinatorial properties of causative morphemes. The insertion of these elements can be realized recursively (see Hakkani-Tür, 2002:382 for examples from Turkish and for discussion of this problem). Other languages, even those which are not genetically akin to Kazakh also exhibit such capacity. It is testified by French series: voir («to see») and faire voir («to make see»). Further on, the latter can reach the form faire faire voir. Ergo, a conclusion can be drawn that the exponents of factitivity in Kazakh language are endowed with special syntagmatic status. It is, as it seems, one more proof of their derivational character. Inflectional morphemes $-i n-,-i H-$ and $-i c-$, despite their regularity, cannot be agglutinated more than once to the lexical item they modify. The forms cerurecicy (< cөürecy «to talk to one anothen» < сөйлеy «to talk to») or mapaнынy (< таранy «to comb one's hair» < mapay «to comb») are not attested in Kazakh lexical system. The reason why these forms are disallowed originates in meanings they convey: they are, as it seems, not amenable to semantic interpretation. The same holds true of the exponents of other grammatical categories (жақссы «good», жақсы-лау «better», *жақсы-лау-лау «better followed by COMP.»). Non-recursive character has been evoked many times in the professional literature as a touchstone of inflectional status of forms that comply with this principle (Scalise, 1988:570). ${ }^{6}$ As has been previously affirmed, the combinations consisting of multiple insertions of one inflectional morpheme are pragmatically incomprehensible.

Before concluding, it seems desirable to comment on the practical dimension of the matters treated herein. As was said above, the distinction between two areas of research acquires significance when deciding how lexicographic works should be drawn up. Once a decision to split Kazakh simple verbs and their factitive counterparts is made, they need to be inserted into two separate dictionary entries. Certainly, serious objections might arise against this point of view. The shortcomings of the solution proposed here are visible especially when derived forms merely introduce information about the order (a purely verbal act) to execute the

${ }^{6}$ This argument does not take care of all doubtful elements in the linguistic status of causative modifiers. The majority of derivational formatives in Kazakh are not repeatable ("рұқссат-нама-нама, ${ }^{*}$ көпиi-лік-тік, *mолеу-ui-ui, etc.). It is exclusively lexical items with a single occurrence of modifying morpheme that are attested in this language (рұқсат-нама - «written permission, visa»; көnuinix - «majority»; mөлеyui - «this who pays, tax-payer»). The mechanisms responsible for this siluation are identical to those forbidding restatement of one and the same inflectional ending. However, similar semantic constraints do not apply to the insertion of causative morphemes. Even multiple occurrences of the latter within the structure of a single verb do not result in distorting its meaning. It is simply a question of several instances of ordering. Scalise (ibid.: 570) presents several examples of multiple insertions of suffixes within a single lexical item. It should be borne in mind, however, that this practice applies more frequently to prefixes. These are iterated mainly for expressive purposes. 
state of affairs signified by a simple verb. It is exactly what takes place in a long series of factitive lexical items: тексеру «to control, to supervise» and тексер$m \kappa i 3-y$ «to make submit to control, to order to supervise». Likewise, the couple сөйлеy «to talk, to speak» and сөйле-ткіз-y «to order to speak, to force to speak» conveys such meaning. It can be rightfully argued that semantic change induced by the insertion of factitive element does not deserve regular encoding in the lexicon. Simply, the correspondence between the meaning and the form is unambiguous and the semantic effect resulting from this modification is fully predictable. Nevertheless, Kazakh lexical system abounds in verbs whose meaning changes radically after the adjunction of causative morphemes (cf. Carstairs-McCarthy, 1998:326). The following two examples illustrate that: бindipy «to make known, to declare, to express» (білу means «to know»), өлmіру «to kill» (derived from өлy, «to die»). It would be interesting to research the origins of this difference. The answer is to be sought inside combinatorial properties of two types of complex verbs. Whereas the former invariably require a subject that designates an animate being (or even a human, dotted with the ability to issue orders), the latter allow for a wider range of entities. Their subjects are semantically far more diversified and may refer to human beings, as well as to natural phenomena, person's acts, etc. In such cases, the semantic difference between simple verbs and their causative counterparts is too important to remain unaccounted for. It seems preferable, then, to introduce both, simple and derived lexical items, under separate dictionary entries. Therefore, it might be concluded that the distinction between inflection and derivation serves to improve the methods currently employed in lexicography which is, undoubtedly, a utilitarian task.

\section{BIBLIOGRAPHY}

Åquist L. (2002), Old Foundations for the Logic of Agency and Action. Studia Logica: an International Journal of Symbolic Logic LXXII (3), 313-338.

Bally Ch. (1926/1996), The Expression of concepts of the personal domain and indivisibility in IndoEuropean Languages, in H. Chappell and W. McGregor (eds.), 1996, The Grammar of Inalienability. Berlin-New York: Mouton de Gruyter, 31-61.

Bańczerowski J. (1999a), Diversity of Flection, in M. Klańska and P. Wiesinger (eds), Vielfalt der Sprachen. Festschrift für Aleksander Szulc zum 75. Geburtstag. Wien: Edition Praesens, 483-504.

B ańczerowski J. (1999b), Toward a grammar of flection. Investigationes Linguisticae VI. 5-84.

B ańko M. (2002), Wykłady z polskiej fleksji. Warszawa: Wydawnictwo Naukowe PWN.

Beard R. (1998), Derivation, in A. Spencer and A.M. Zwicky (eds), The Handbook of Morphology. Oxford-Malden: Blackwels Publishers, 44-65.

Bogusławski A. (1992), Two Essays on Inflection. Warszawa: Energeia.

Bybee J.L. (1985), Morphology. A study of the relation between meaning and form. AmsterdamPhiladelphia: John Benjamins (Typological Studies in Language 9). 
Carstairs-McCarthy A. (1998), Paradigmatic Structure: Inflectional Paradigms and Morphological Classes, in A. Spencer, A.M. Zwicky (eds), The Handbook of Morphology. Oxford-Malden: Blackwell Publishers, 322-344.

Carvalho de P. (1996), «Partitif», génitif, article: pour renverser l'inverseur et repenser l'article français. Bulletin de la Société de Linguistique de Paris XCI (1). 169-221.

Corbett G.G. (1987), The Morphology/Syntax Interface: Evidence from Possessive Adjectives in Sla. vonic. Language 63 (2). 299-345.

Dalrymple M., M. Kanazawa, Y. Kim, S. Mchombo, S. Peters (2001), Reciprocal Expressions and the Concept of Reciprocity. Linguistics and Philosophy 21 (2). 159-210.

Goldberg A.E. (2001), Patient arguments of causative verbs can be omitted: the role of information structure in argument distribution. Language Sciences 23 (4-5). 503-524.

Hakkani-Tür D.Z., K. Oflazer, G. Tür (2002), Statistical Morphological Disambiguation for Agglutinative Languages. Computers and the Humanities 36 (4). $381-410$.

Heinz A. (1961), Fleksja a derywacja. Język Polski XLl (5), pp. 343-354.

Johanson L. (1998), Code-copying in Irano-Turkic. Language Sciences 20 (3). 325-337.

Karolak S. (1990), Kwantyfikacja a determinacja w jezykach naturalnych. Warszawa: PWN.

Kempf Z. (1975), O przypadkach sprzęzonych. Prace Filologiczne XXV. 147-154.

La miroy B. (1993), L'incomplétude du passif dans les langues romanes, en S. Karolak, T. Muryn (eds), Complétude et incomplétude dans les langues romanes et slaves. Actes du VI colloque international de linguistique romane et slave. Cracovie 29 septembre - 3 octobre 1991. Kraków: Ecole Normàle Supérieure - Institut d'Etudes Romanes, 241-266.

Matthews P.H. (1991), Morphology. Cambridge: Cambridge University Press.

Nagórko A. (1993), Czy istnieje slowotwórstwo?, in J. Sambor, J. Linde-Usienkiewicz, R. Huszcza (eds), Językoznawstwo synchroniczne i diachroniczne. Tom poświęcony pamięci Adama Weinsberga. Warszawa: Wydawnictwa Uniwersytctu Warszawskiego, 203-213.

Nkollo M. (2002), L'actualisation des cas à l'exemple du comitatif français. Biulctyn Polskiego Towarzystwa Językoznawczego LVIII, 121-135.

Paduce va E.V. (2002), Diateza i diaticeskij sdvig. Russian Linguistics 26 (2), 179-215.

Plank F. (1999), Split morphology: how agglutination and flexion mix. Linguistic Typology 3 (3), 279-340.

Scalise S. (1988), Inflection and derivation. Linguistics 26 (4), 561-581.

Spencer A. (2000), Inflection and the Lexeme. Acta Linguistica Hungarica XLVII (1-4), 335-344.

Williams E. (1981), On the Notions "lexically related" and "head of word". Linguistic Inquiry 12 (2), 245-274.

Wójcik P. (2000), The Acquisition of Lithuanian Verb Morphology. A case study. Kraków: Uniwersytet Warszawski (Katedra Językoznawstwa Ogólnego i Baltystyki) - Universitas. 